PEMBELAJARAN MATEMATIKA DI MASA PANDEMI BAGI GURU SD KECAMATAN BABAT SUPAT (KAJIAN RESPON PELATIHAN)

\author{
Marhamah $^{1}$, Anggria Septiani Mulbasari ${ }^{2}$, Ety Septiati $^{3}$, Lusiana $^{4}, \mathrm{Jumroh}^{5}$ \\ Program Studi Pendidikan MatematikaUniversitasPGRI Palembang ${ }^{1,2,3,4,5}$ \\ marhamah1904@gmail.com, tia.pasca@yahoo.co.id, etyseptiati@univpgri- \\ palembang.ac.id, luu.sii.ana@gmail.com,jumroh.dahlan@gmail.com.
}

\begin{abstract}
Abstrak
Pembelajaran matematika yang menyenangkan di masa pandemi bagi guru SD Kecamatan Babat Supat merupakan salah satu kegiatan tri dharma perguruan tinggi yaitu suatu pelatihan yang merupakan kegiatan pengabdian kepada masyarakat. Adapun Tujuan Kajian Respon Pelatihan ini bertujuan untuk mengetahui Respon Guru-guru sebagai peserta pelatihan yang telah dilakukan oleh Dosen-Dosen Prodi Matematika FKIP UPGRI Palembang di Kecamatan Babat Supat dalam pelaksanaan pembelajaran yang menyenangkan di masa pandemi. Manfaat kajian Respon pelatihan ini dapat dipergunakan sebagai acuan peningkatan kualitas penyelenggaraan pelatihan pada kegiatan pengabdian kedepannya. Metode yang digunakan untuk memperoleh respon peserta pelatihan adalah metode kuesioner, dengan memberikan angket kepada peserta setelah mengikuti pelatihan. Berdasarkan analisis angket respon yang disebarkan kepada 30 peserta pelatihan, diperoleh hasil 83,86\% memberikan respon sangat baik terhadap materi pelatihan, $84,26 \%$ memberikan respon sangat baik terhadap nara sumber dan 86,53\% memberikan respon sangat baik terhadap fasilitas penyelenggaraan pelatihan. Jadi dapat disimpulkan bahwa dari kajian respon pelatihan yang dilakukan telah memberikan kontribusi kepada guru-guru di SD Kecamatan Babat Supat, yakni guru memperoleh wawasan tentang pembelajaran matematika yang menyenangkan di masa pandemi.
\end{abstract}

Kata kunci:Matematika, Pelatihan, Respon

\begin{abstract}
Learning mathematics that is fun during the pandemic for elementary school teachers in Babat Supat District is one of the tri dharma tertiary activities, namely a training which is a community service activity. The objective of this training response study is to determine the responses of teachers as training participants that have been carried out by Lecturers of the UPGRI Palembang FKIP Mathematics Study Program in Babat Supat District in implementing fun learning during the pandemic. Benefits of the study The training response can be used as a reference for improving the quality of training delivery in future service activities. The method used to obtain responses from training participants is the questionnaire method, by providing questionnaires to participants after attending the training. Based on the analysis of the response questionnaire distributed to 30 training participants, the results obtained were $83.86 \%$ gave very good responses to training materials, $84.26 \%$ gave very good responses to resource persons and $86.53 \%$ gave very good responses to the training facilities. So it can be concluded that from the study of the training response that was carried out it had contributed to the teachers in SD Babat Supat District, namely teachers gained insight into fun mathematics learning during the pandem
\end{abstract}

Keywords:Mathematics, Training, Response

Artikel disetujui tanggal:24-06-2021

Corresponden Author:Marhamah e-mail:marhamah@mail.com

DOI: http://dx.doi.org/10.31851/dedikasi.v4i2.5702 do9 


\section{VAHANA DEDIKASI}

\section{PENDAHULUAN}

Salah satu sektor yang terkena dampak dari keganasan virus corona di Indonesia adalah sektor pendidikan. Sehingga pemerintah melalui kementerian pendidikan dan kebudayaan Indonesia mengambil langkah cepat dan antisipasi dini dengan menetapkan semua proses belajar mengajar di lakukan dari rumah atau secara daring, hal tersebut sebagai upaya pencegahan penularan virus Corona dan juga menjawab tantangan revolusi industri 4.0, mengingat sekolah merupakan salah satu tempat berkumpulnya manusia dalam jumlah banyak(Kemendikbud, 2020b). Selanjutnya memperkuat SE Mendikbud nomor 4 tahun 2020, Kemendikbud menerbitkan surat Surat Edaran Nomor 15 Tahun 2020 tentang bagaimana pedoman dalam menyelenggarakan proses belajar secara daring dimasa darurat Covid19 (Apriyanto et al., 2021). Dalam pedoman surat edaran tersebut dijelaskan bahwa tujuan yang ingin dilakukan dalam menjalankan Proses Belajar Dari Rumah (BDR) yaitu dapat memenuhi hak dari anak didik berupa pelayanan pendidikan yang tetap berjalan selama masa tanggap darurat tersebut, melindungi dari dampak buruk terhadap warga satuan pendidikan, memutus mata rantai penyebaran dan penularan dalam satuan pendidikan dan memberikan dukungan penuh dampak psikososial terhadap para guru, anak didik, dan para orang tua, serta merekomendasikan sebanyak 23 laman yang dapat diakses oleh orangtua dan guru sebagai sumber belajar anak didik dirumah selama masa

darurat

covid-19

(Kemendikbud, 2020a).

Pengalihan belajar dari rumah tersebut tidak hanya berdampak terhadap pendidikan tinggi dan menengah saja, tetapi dunia pendidikan paling dasar seperti pendidikan sekolah dasar.

$$
\text { Salah satu sistem }
$$

pembelajaran yang dapat digunakan sebagai sarana untuk proses belajar mengajar yang dilaksanakan tanpa harus bertatap muka secara langsung antara guru dengan siswa adalah daring (Andriansyah, 2013).(Putri \& Dewi, 2020) menyatakan bahwa seiring perkembangan zaman, seseorang dapat memperoleh informasi secara mudah melalui teknologi baru yang terus berkembang. Perkembangan teknologi ini menguntungkan dibidang pendidikan bagi guru maupun siswa dalam proses pembelajaran (Sodikin etal., 2021). Melakukan proses pembelajaran dari rumah secara online atau daring tidak semudah yang dibayangkan seperti yang dikatakan (Rusdiana et al., 2020)Begitu banyak hal yang harus dipikirkan dan dipertimbangkan demi tercapainya tujuan pembelajaran yang kita rancangkan sebelumnya, diantaranya strategi pembelajaran, metode, model bahkan ketersediaan fasilitas yang menunjang dalam melakukan pembelajaran online atau daring tersebut.

Adapun manfaat dari kegiatan belajar matematika secara daring, yaitu dengan dapat mempersingkat waktu pembelajaran atau lebih praktis dan membuat biaya pelajaran lebih ekonomis, belajar secara daring juga 


\section{WAHANA DEDIKASI}

dapat mempermudah interaksi siswa dengan bahan materi yang telah diberikan, siswa juga dapat saling berbagi informasi dan dapat mengakses bahan belajar setiap saat hingga berulang-ulang, dan belajar secara merupakan proses pengembangan pengetahuan tidak hanya terjadi di dalam ruangan kelas saja, tetapi di luar kelas atau di rumah (study at home) dengan bantuan peralatan teknologi dan jaringan internet, sehingga para siswa dapat aktif terlibat dalam proses belajarmengajar (Rohmah, 2011).

Denganpelaksanaan pembelajaran dari rumah secara daring, guru dituntut untuk lebih inovatif dalam menyusun langkah-langkah pembelajaran, agar pembelajaran menjadi lebih menyenangkan walaupun dilakukan secara daring atau online. Perubahan cara mengajar ini tentunya membuat guru dan siswa beradaptasi dari pembelajaran secara tatap muka di kelas menjadi pembelajaran daring (Mastuti et al., 2020).

Beberapa penelitian sebelumnya menyatakan hasil belajar pembelajaran daring lebih baik daripada pembelajaran tatap muka (Means et al., 2013; Radita et al., 2018), sedangkan penelitian yang lain menyebutkan bahwa hasil belajar yang menggunakan pembelajaran tatap muka lebih baik daripada yang menggunakan pembelajaran daring (Al-Qahtani \& Higgins, 2013).

Kegiatan ini diharapkan dapat menghilangkan keraguan guru SD di Kecamatan Babat Supat dalam penyampaian materi matematika secara online yang terkesan akan sulit dipahami dibanding secara offline, juga berusaha untuk menghilangkan image peserta didik bahwa matematika itu sulit, menakutkan dan membosankan.

Sekolah yang menjadi sasaran dalam kegiatan pengabdian kepada masyarakat mengenai pembelajaran matematika yang menyenangkan di masa pandemi bagi guru SD adalah sekolah yang berada di Kecamatan Babat Supat yang terdiri dari SD Negeri 1 Gajah Mati, SD Negeri 2 Gajah Mati, SD Negeri 3 Gajah Mati, SD Negeri 4 Gajah Mati, SD Negeri 1 Tanjung Karang, SD Negeri 2 Tanjung Karang, dan SLB Rimba Asam.

\section{METODE PELAKSANAAN}

Metode kegiatan yang dilakukan dalam pengabdian kepada masyarakat ini adalah dalam bentuk pelatihan pembelajaran matematika yang menyenangkan seperti menggunakan jarimatika (Hamdunah et al., 2014) perkalian $6-10$ untuk pembelajaran online, perkalian menggunakan tabel diagonal dan pembelajaran matematika berbasis proyek. Untuk memantapkan pengetahuan guru dalam pembelajaran matematika yang menyenangkan, maka dilakukan juga bimbingan secara online melalui Whatshaap Group. Pelatihan inu diakhiri dengan pengisian angket oleh guru-guru peserta pelatihan guna mengetahui sejauh mana manfaat yang diperoleh guru-guru setelah mengikuti kegiatan pelatihan ini dan untuk mengevaluasi proses pelatihan yang sejenis dimasa yang akan datang. 


\section{WAHANA DEDIKASI}

\section{HASIL DAN PEMBAHASAN}

Pelatihan pembelajaran yang menyenangkan di masa pandemi dilakukan pada tanggal 14 Desember 2020 bertempat di SD Negeri 3 Gajah Mati Kecamatan babat Supat Kabupaten Musi Banyuasin dengan narasumber Marhamah, M.Pd, Anggria Septiani Mulbasari, M.Pd, Ety Septiati, S.T, M.T, Dra. Lusiana, M,Pd dan Dra. Jumroh, M,Pd yang merupakan Dosen Pendidikan matematika Fakultas Keguruan dan Ilmu Pendidikan Universitas PGRI Palembang, selain Dosen kegiatan ini juga melibatkan dua orang mahasiswa berprestasi dari program studi matematika yaitu Achmad Amin Setiabudi dan Lingga Anzalna. Kegiatan pengabdian kepada masyarakat ini di buka oleh ketua Lembaga Penelitian dan Pengabdian kepada Masyarakat (LPPkM) Universitas PGRI Palembang yaitu Ibu Dr. Rohana, M,Pd. Diakhir kegiatan ini tim pengabdian kepada masyarakat menyebarkan angket respon yang bertujuan untuk mengetahui manfaat pelatihan serta memperoleh gambaran sejauh mana efektifitas dan efisiensi pelatihan yang dilakukan. Kegiatan ini diikuti oleh 30 orang guru Sekolah Dasar yang ada di kecamatan Babat Supat Kabupaten Musi Banyuasin yang berlatar belakang pendidikan matematika.

Antusias para peserta pentingnya kegiatan pelatihan ini, hal ini dibuktikan dari kehadiran peserta pelatihan yang mengikuti pelatihan dari awal sampai selesainya pelatihan dan mereka mewakili masing-masing Sekolah Dasar yang berada di
Kecamatan Babat Supat Kabupaten Musi Banyuasin (dapat dilihat pada gambar berikut).

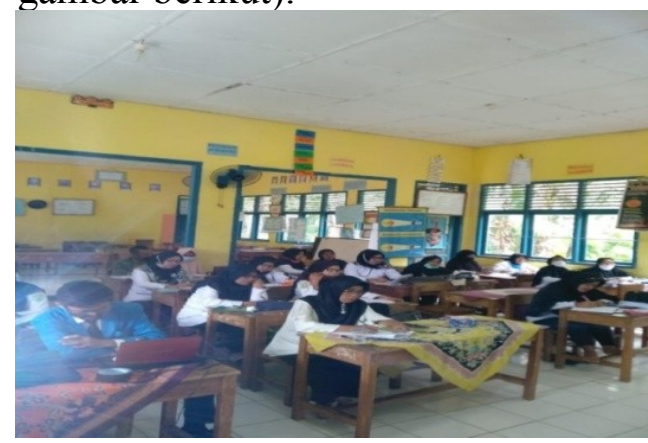

Gambar 1. Suasana Pelatihan dan Pengisian Angket

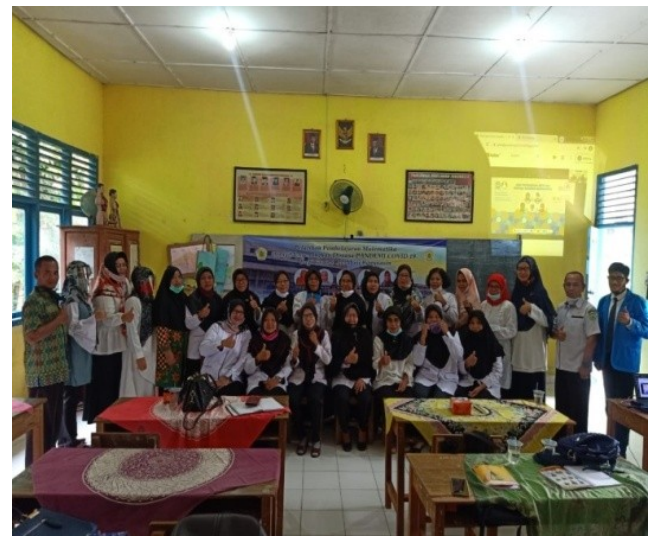

Gambar 2.Pemateri dan Peserta Pelatihan

Berdasarkan analisis angket respon yang disebarkan kepada 30 peserta pelatihan setelah selesai melakukan pelatihan diperoleh hasil sebagai berikut : $83,86 \%$ memberikan respon sangat baik terhadap materi pelatihan, dengan butir-butir instrumen materi pelatihan : sesuai dengan kebutuhan peserta, materi pelatihan dapat diterima dan diterapkan dengan mudah, materi pelatihan disampaikan dengan urut dan sistematikanya jelas, tulisan di dalam materi pelatihan jelas dan mudah dibaca serta kualitas materi pelatihan dapat menambah tingkat keterampilan dan pengetahuan anda. 


\section{WAHANA DEDIKASI}

$84,26 \%$ memberikan respon sangat baik terhadap nara sumber dengan butir-butir instrumen nara sumber : narasumber menguasai materi yang disampaikan, narasumber menyajikan materinya dengan jelas dan bahasanya mudah dimengerti, narasumber memberikan kesempatan tanya jawab, narasumber memberikan materi secara sistematis/berurutan dan narasumber menciptakan suasana kondusif. Untuk fasilitas penyelenggaraan pelatihan diperoleh respon sangat baik sebesar $86,53 \%$ adapun butir-butir instrumen untuk fasilitas penyelenggaran : kegiatan dilaksanakan dengan memperhatikan protokol kesehatan, kegiatan didukung dengan fasilitas presentasi (powerpoint dan infocus), setiap peserta mendapatkan handout (materi) pelatihan, ruangan pelatihan baik dan bersih bagi peserta, dan konsumsi yang disediakan sudah memuaskan bagi peserta.

Sebagian besar dari guru-guru peserta pelatihan juga menyatakan akan mengikuti kembali jika ada pelatihan berikutnya. Penjabaran detail dari hasil angket respon yang telah disebar kepada peserta pelatihan menunjukkan bahwa kegiatan pelatihan ini telah memberikan konstribusi yang positif kepada guruguru SD di Kecamatan Babat Supat Kabupaten Musi Banyuasin yakni guru memperoleh wawasan tentang pembelajaran matematika yang menyenangkan di masa pandemi.

\section{KESIMPULAN}

Berdasarkan hasil yang diperoleh dalam pelaksanaan kegiatan Pengabdian Kepada Masyarakat ini dapat disimpulkan bahwa kegiatan ini telah memberikan kontribusi kepada guru-guru SD di Kecamatan Babat Supat Kabupaten Musi Banyuasin, yakni cara pembelajaran matematika yang menyenangkan di masa pendemi. Berdasarkan analisis angket respon yang disebarkan kepada 30 orang peserta pelatihan memberikan hasil sebagai berikut 83,86 \% memberikan respon sangat baik terhadap materi pelatihan, 84,26\% memberikan respon sangat baik terhadap nara sumber dan 86,53\% memberikan respon sangat baik terhadap fasilitas penyelenggaraan pelatihan.

Kepada guru-guru Sekolah Dasar yang telah mengikuti kegiatan ini agar bisa mentransfer ilmu dan pengalamannya kepada guru-guru lainnya yang belum memiliki kesempatan untuk mengikuti pelatihan ini, agar siswa merasa senang belajar matematika meskipun dalam kondisi pandemi.

\section{DAFTAR PUSTAKA}

Al-Qahtani, A. A. Y., \& Higgins, S. E. (2013). Effects of traditional, blended and elearning on students' achievement in higher education. Journal of Computer Assisted Learning, 29(3), 220-234. https://doi.org/10.1111/j.13652729.2012.00490.x

Andriansyah, I. (2013). Eksplorasi Pola Komunikasi dalam Diskusi Menggunakan Moodle pada Perkuliahan Simulasi Pembelajaran Kimia. Universitas Pendidikan Indonesia.

Apriyanto, M., Oklianda, A., Putra, 


\section{WAHANA DEDIKASI}

D. D., \& Warmi, A. (2021, February). Student Responses During Online Learning in the Covid-19 Pandemic Period. In Journal of Physics: Conference Series (Vol. 1764, No. 1, p. 012125). IOP Publishing.

Hamdunah, Fitri, D. Y., \& Cesaria, A. (2014). Pelatihan Jarimatika Perkalian Bagi Guru-Guru. Lemma, I(1), 20-25.

Kementerian Pendidikan Dan Kebudayaan. (2020).

Pedoman Penyelenggaraan Belajar Dari Rumah Dalam Masa Darurat Penyebaran Corona Virus Disease (Covid19). Surat Edaran Nomor 15 Tahun 2O2O, 021, 1-20.

Kementerian Pendidikan dan Kebudayaan Republik Indonesia. (2020). Surat Edaran Menteri Pendidikan dan Kebudayaan Republik Indonesia Nomor 35952/MPK.A/HK/2020.

Mendikbud RI, 1-2. https://www.kemdikbud.go.id

Mastuti, R., Maulana, S., Iqbal, M., Faried, A. I., Arpan, A., Hasibuan, A. F. H., Wirapraja, A., Saputra, D. H., Sugianto, S., \& Jamaludin, J. (2020). Teaching from home: Dari belajar merdeka menuju merdeka belajar. Yayasan Kita Menulis.

Means, B., Toyama, Y., Murphy, R., \& Baki, M. (2013). The effectiveness of online and blended learning: A metaanalysis of the empirical literature. Teachers College Record, 115(3).
Putri, L. A., \& Dewi, P. S. (2020). Media Pembelajaran Menggunakan Video Atraktif pada Materi Garis Singgung Lingkaran. Mathema: Jurnal Pendidikan Matematika, 2(1), 32. https://doi.org/10.33365/jm.v2 i1.568

Radita, N., Aminah, S., \& Kanthi, Y. A. (2018). Eksperimentasi Pembelajaran Matematika Diskrit Moda Daring Pada Program Studi Teknik Informatika. MUST: Journal of Mathematics Education, Science and Technology, 3(2), 165-174.

Rohmah, L. (2011). Konsep ELearning dan Aplikasinya pada Lembaga Pendidikan Islam. Al-Tadzkiyyah: Jurnal Pendidikan Islam, 8(1), 99.

Rusdiana, A., Sulhan, M., Arifin, I. Z., \& Kamludin, U. A. (2020). Penerapan Model POE2WE Berbasis Blended Learning Google Classroom Pada Pembelajaran Masa WFH Pandemic Covid-19. Scientific Writing of the Bandung State Islamic University 2020, 1-10

Sodikin, A., \& Yulianto, A. T. (2021). Pendampingan Pembelajaran Daring Bagi Santri Pondok Pesantren Nurul Huda Tanah Merah. Wahana Dedikasi: Jurnal PkM Ilmu Kependidikan, 4(1), 134-141.. 